\title{
TEACHING THE USES OF ITALIAN VERB FORMS TO SLOVENE SPEAKERS
}

\author{
In fact you know only when you know little. Along \\ with knowledge doubt grows. (J. W. Goethe)
}

\section{INTRODUCTION}

Goethe's paradoxical aphorism concerning our knowledge of complex phenomena could be used to identify the feelings which may prevail at two different stages of learning a foreign language, at an early and at an advanced one. So, for example, it is not surprising when our students, back from an exchange visit abroad, complain about having felt blocked by their thorough structural language awareness, noticing at the same time that some other foreign students showed off their fluency and richness of vocabulary, while calmly violating certain grammatical conventions. ${ }^{1}$ Such self-conscious learners seem to miss their past lack of inhibitions, when they still naively thought of language differences principally as neatly observable dissimilarities in language forms, feeling that their present awareness of more hidden foreign-language properties is rather a disadvantage in communication; so much so that they wonder whether it would not have been better to have invested all that time and energy into the acquisition of the lexicon instead.

But since a natural language is an extremely complex phenomenon, for the relatively successful learning of which great effort is necessary, the question about what aspects of it are to be taught to whom, how, when, where, why, etc. can only be dealt with properly if several parameters are taken into account. Reporting on our own experience of foreign-language teaching, we would like to point out that at the Department of Italian language of the University of Ljubljana great emphasis has for years been put on the structural aspects of Italian on the one hand and of Slovene as the mother tongue of the majority of the students on the other (see Uršič et al. (eds) 2000, Miklič 1986, 1992a, $1992 \mathrm{~b}, 1993$ ). There are mainly two reasons for that. The first one is of sociolinguistic nature: Slovenia is a small country and Slovene a minor language (about two million speakers), and in any kind of cross-cultural communication involving this language it will inevitably be Slovene speakers who will normally have to put their mother tongue aside and make use of a major language. ${ }^{2}$ Accordingly, a thorough productive mastery of

\footnotetext{
Obviously, they seem not to have realized that the rich vocabulary admired in their peers was mainly due to numerous common Romance or Greek and Latin roots which their mother tongues share with Italian, whereas Slovene contains principally words of Slavic origin.

2 It is simply a fact that, while countries like Slovenia strive to potentiate their foreign language teaching, in Great Britain single foreign language departements are being closed down (cfr. numerous reports on the problem in virtually every issue of the Times Highier Education Supplement over the past couple of years), as if private language shools intended for potential British travellers abroad could cover the principal foreign language needs of the population.
} 
different languages, including their grammatical aspects, is of vital importance to Slovene learners if they wish to be able to communicate cross-culturally with some competence and with the necessary self-confidence. ${ }^{3}$ The second reason for emphasizing the structural aspects of the Italian language is its intrinsic character: Italian has a relatively high number of »tenses« which are not at all relegated to written texts (with the exception of one of them), but are actually used in everyday communication: combined with other language elements and constructions, they serve to express not only temporal, aspectual and modal meanings, but also important logico-semantic contents. ${ }^{4}$ Since the differences in the selection principles are often difficult to recognize - unless they have been pointed out to the learner in an explicit way - it is our conviction that in the teaching process those language properties must be stressed which would otherwise remain unnoticed.

Errors related to the use of verb forms in foreign languages are, of course, very widespread and instead of examples from the Slovene-Italian language pair it is easy to think of much more common English sentences such as the ones below, frequently produced by Slavic, Greek, Arabic and other speakers. It is often possible to hear such sentences in TV interviews, and their authors may be politicians, diplomats, scientists, and other experts, i. e. persons who have evidently received good general and specialist education and who have often had a great deal of foreign language practice:

1. We are working on the project already for two years (instead of: have been working).

2. You will see it when you will come (instead of: when you come) to the door.

3. If he would be still alive (instead of: If he were/was) we would certainly act differently.

4. We knew that at two o'clock the door will be (instead of: would be) opened.

All these sentences reveal deep-rooted non-English, mostly mother-tongue tense selection principles and can be interpreted as evidence of an inadequate teaching approach. What can be done to enable the learner to successfully overcome such difficulties in the use of verb forms? Returning to the two languages of our primary concern, let us first analyze the current situation and then see what the solutions to this problem could be.

\section{THE COMPLEXITY OF THE ITALIAN VERB SYSTEM AND SLOVENE SECONDARY SCHOOLS}

In the Italian language all fourteen tenses and the five impersonal forms distributed in four groupings of tense forms are actually used: eight of the indicative type (presente $(P r)$, passato prossimo (PP), futuro (F), futuro composto (FF), imperfetto (IM), passato remoto (PR), trapassato prossimo (TP), trapassato remoto (TR)), four of the subjunctive type (presente (Pr'), passato ( $\left(P^{\prime}\right)$, imperfetto (IM'), trapassato (TP') del congiuntivo),

3 In Slovenia, Italian is one of the most important foreign languages, on the one hand because it is the language of a neighbouring country with which close contacts have for centuries existed at various levels (cultural, economic, political, etc.), and, on the other, because it has the status of an official language in the bilingual Coastal area (districts of Koper, Izola, Piran, and Portorož).

4 Numerous studies on various aspects of the learning and acquisition of the Italian verb system by foreigners have been made. See Giacalone Ramat (ed.) 1988, Banf/Giacalone Ramat 2003, Barni, Carloni/Lucarelli 2003, Miklič 1991, 1992a, 1992b, 2003, Moderc 2003, to mention but a few. 
two conditionals (condizionale semplice $(C)$, condizionale composto (CC)) and five impersonal forms (infinito semplice (INF), infinito composto (INFF), gerundio semplice $(G)$, gerundio composto (GG), participio passato (PART)). ${ }^{5}$

The Slovene language, on the other hand, has in principle six tenses, but practically only four appear in actual texts: sedanjik (»present«), preteklik (»past«), prihodnjik (»future «), sedanji pogojnik (»present conditional«), predpreteklik (»past perfect«) and pretekli pogojnik (»past conditional«). The impersonal forms (the infinitive and the participles) are seldom used, at least in subordinate clausal constructions. ${ }^{6}$

If the difference in the very numbers of the tenses of the two systems is so considerable, what results can then be expected from Slovene learners of Italian at the end of secondary school, after they have studied the language for four, eight, or, in the ethnically mixed Italian-Slovene area in the Coastal region, even twelve years? ${ }^{7}$ Although no precise answers can be given, we do have some important indications of the situation. First, an assessment of the syntactic knowledge of learners after their baccalaureate in Italian (cfr. Mertelj 2005) has shown that those common syntactic constructions which require morphologically complex verb forms (above all the four subjunctives) are practically absent from the texts produced by the learners. A case in point are constructions introduced by the conjunctions such as the following: se/if/, come se /as if/, perché /so that/, prima che /before/, senza che /without/, etc. These important syntactic patterns are also virtually absent from the textbooks used, and consequently from the classroom as well. Second, for some years now, in our Italian Department, freshmen's productive knowledge of certain aspects of tense selection principles in other foreign languages they have studied has been systematically tested. The subjects are first asked to answer questions about which foreign languages they have studied, where (name and type of school; if they learned a language in different ways, e.g. from the TV or from audio cassettes, they are asked to report on those too), and for how long; then they have to express in each of the languages studied the content of three sentences given to them in their mother tongue. What is being tested is their ability to express a temporal relation in a future situation as well as a hypothetical relation in a non-past and in a past situation:

4. Ko bom to vedela, ti bom povedala.

5. Če bi bilo lepo vreme (zdaj), bi šli ven. [now]

6. Če bi bilo lepo vreme (včeraj), bi šli ven. [yesterday]

/ 4.a When I know it, I will tell you.

5.a If the weather were fine we would go out.

6.a If the weather had been fine we would have gone out./

5 For a verb like "partire ( $»$ to leave ), a complete list of 1 st person feminine tense forms is as follows: parto, sono partita, partirò, sarò partita, partivo/stavo partendo, partii, ero partita, fui partita; parta, sia partita, partissi, fossi partita; partirei, sarei partita; partire, essere partita, partendo, essendo partita, partita. There is yet a sixth impersonal form, the participio presente ("spartente $)$, the use of which is rather restricted.

6 For a perfective/imperfective verb pair like »oditi/odhajati« (»to leave«), a complete list of 1st person feminine tense forms is as follows: odidem/odhajam, odšla sem/odhajala sem, odšla bom/odhajala bom, odšla bi/odhajala bi, odšla sem bila/ odhajala sem bila, odšla bi bila, odhajala bi bila.

7 As can be expected, interferences from Slovene are very common at all learning levels (see Miklič 1992b); these negative transfers may sometimes be particularly hard to eliminate because of their presence in certain (mainly spoken) varieties of Slovene to which learners of Italian may be exposed (cfr. Ožbot 1995/96). 
With too many candidates, the answers in Italian (their chosen subject) and in English (the most extensively taught foreign language in Slovenia), not to speak of other languages - German, French, Spanish - regularly show great insecurity or even ignorance of the principles of tense choice. More than $60 \%$ of the answers are wrong, sometimes regardless of the duration of the time span over which a student has been learning the language in question. If they perform rather poorly in a written task, in which they do have time for reflection, even worse results could be expected in their spontaneous, oral performance. According to these results, then, many Slovene learners aged eighteen, who have received considerable formal foreign-language instruction, are not able to express in foreign languages they have studied such important logico-semantic relations as condition, purpose, comparison, posteriority, etc., whereas the presence of, for instance, Slovene hypothetical conditional clauses can be noticed in spontaneously produced speech of Slovene children not older than three or four. How can such a situation be accounted for?

\section{DIFFERENCES IN THE SELECTION PRINCIPLES}

Leaving aside the situation in bilingual communities or mixed ethnic groups, the study of a new language begins normally at a point when the person has already acquired the most important elements of lexical, pragmatic, cultural, and, of course, grammatical aspects of his/her mother tongue (cfr. Braidi 1999: $40 \mathrm{ff}$.). Now, a frequent learning strategy is generalization, i.e. recognition of previously known properties in new elements, and in foreign language learning the terminology referring to present $(P r)$, past $(P)$ and future $(F)$ tenses, to conditionals $(C)$ and to subjunctives in different languages encourages the learner to draw false conclusions about their allegedly universal values: he/she therefore tends to generalize that the tenses may well be different in form and number, but they nonetheless have to perform more or less the same functions. The difficulty is that this is mostly true of indipendent clauses, whereas in numerous subordinate syntactic constructions the selection principles of tense choice can vary drastically. And this is the very problem with the Slovene and Italian verb systems.

Returning to the three semantic contents in 4., 5., and 6. we can observe that in the first temporal clause in Slovene as well as in Italian - but not in English -, the respective FUTURE tense is used. But whereas in if-clauses, in English like in Italian, four different forms are necessary, ${ }^{8}$

4.b Quando lo saprò te lo dirò.

5.b Se facesse bel tempo usciremmo.

6.b Se avesse fatto bel tempo saremmo usciti.

in Slovene one and the same form - the PRESENT CONDITIONAL - is used invariably:

$\begin{array}{llll} & \text { Slov. } & \text { Ital. } & \text { Engl. } \\ \text { 4.' when } & \mathrm{F} / \mathrm{F} & \mathrm{F} / \mathrm{F} & \operatorname{Pr} / \mathbf{F} \\ \text { 5.' if } & \underline{\mathbf{C}} / \mathbf{C} & \text { IMsub } / \mathbf{C} & \mathbf{P} / \mathbf{C} \\ \text { 6.' if } & \underline{\mathbf{C}} / \underline{\mathbf{C}} & \text { TPsub } / \mathbf{C C} & \text { TP } / \mathrm{CC}\end{array}$

8 These are the imperfetto del congiuntivo, the condizionale composto, the trapassato del congiuntivo, and the condizionale composto; the past tense, the present conditional, the past perfect, and the past conditional. 
The urge, then, in Slovene speakers, to extend the principle followed in their mother tongue to foreign language material is considerable and can be observed in a great deal of their foreign-language text production. In the choice of the Italian tense forms, such objective learning difficulties affect all the central semantic areas of the verb usage: temporal, aspectual and modal ones.

So, as far as the temporality is concerned, an average Slovene speaker is not at all aware of a feature of the Slavic languages, which consists in different principles of expressing relative temporal relations for past actions (anteriority, simultaneity and posteriority) in dependence of the type of syntactic construction. For example, a simultaneous action in a Slovene THAT- or WH-clause is realized by the »present tense « (sedanjik), while in a relative clause and in most adverbial clauses it is realized by the "past tense (preteklik). On the other hand, in Italian (like in English) the same principle holds for both syntactic constructions and consequently no distinction is made in the tense forms used (imperfetto in Italian and past tense/past perfect in English):

7. Vedela je, da Vid pripravlja nov učbenik (sedanjik / /present tense«) (She knew that Vid was preparing a new textbook/ had been prepairing.) Sapeva che Vid stava preparando un nuovo libro di testo.

8. Sestala se je s Vidom, ki je pripravljal nov učbenik. (preteklik /»past tense«) (She met Vid, who was preparing a new textbook / had been prepairing.) Incontrò Vid, che stava preparando un nuovo libro di testo.

Similarly, there is no real correspondence in the fundamental selection principles between aspectual verb pairs: the IMPERFETTO/IM/ vs the PERFETTO/P/ in Italian and the IMPERFECTIVE $v s$ the PERFECTIVE VERBS in Slovene (nedovršniki $/ \mathrm{ND} /$ vs. dovršniki /D/, cfr. Miklič 1983). In actual fact, if there are numerous cases of superficial overlap between the so-called perfective forms on the one hand $(\mathrm{D}-\mathrm{P})$ and between the imperfective ones on the other (ND - IM):

9. Ko se je vrnila (D), so še vedno popravljali (ND) njen avto.

(When she returned, they were still repairing her car.)

Quando è tornata (P), stavano ancora riparando (IM) la sua macchina,

there are also many cases of systematic lack of correspondence (ND - P, D - IM):

(ND - P)

10. Nekaj časa je čakala (ND), potem je odšla.

(She waited for a while, then she left.)

Aspettò (P) per un po', poi se ne andò via.

(D - IM)

11. Kadarkoli je vprašala (D), so ji odgovorili (D).

(Whenever she asked a question, she got an answer.)

Ogni volta che domandava (IM) le rispondevano (IM). 
Finally, even less correspondence between Slovene and Italian can be observed in the uses of verb forms which contribute primarily to the expression of modality. A case in point is the Italian pluperfect subjunctive (trapassato del congiuntivo), which, depending on the syntactic and/or semantic context, can be rendered by each of the six Slovene tenses:

12. È stato più caro di quanto non AVESSIMO PREVISTO. (»pluperfect«: Bilo je dražje, kot smo bili predvideli.) /It was more expensive than we expected./

13. Raccontò di come Antonio FOSSE TORNATO prima. (»past«: Povedal je, da se je Tone vrnil prej). /He told that Tony returned earlier./

14. Parla l'inglese come se AVESSE STUDIATO in Inghilterra. (»past conditional«: Angleško govori, kot da bi bil študiral v Angliji). /He speaks English as if he had studied in England./

15. Conosceva il paese come se ci FOSSE già STATO. (»present conditional«: Deželo je poznal, kot da bi tam že bil). /He knew the country as if he had already been there./

16. Era rosso come se AVESSE AVUTO la febbre. (»present«: Rdeč je bil, kot da ima vročino). $/ \mathrm{He}$ was red in the face as if he had fever./

17. Disse che l'avrebbe regalata al primo che FOSSE PASSATO. (»future«: Rekel je, da jo bo podaril tistemu, ki bo prvi prišsel mimo). /He said he would give it to the first one who passed by./

Likewise, the Slovene simple conditional (pogojnik) is used in contexts in which again, depending on syntactic, semantic and pragmatic factors - in Italian any of the forms of the two conditionals or of the four subjunctives would be possible. For instance, the Slovene BI VIDEL (»would see«) has several equivalents in Italian: vedrebbe/ avrebbe visto/ senza che veda/ senza che vedesse/ senza che abbia visto/ senza che avesse visto:

18. Če bi bolje pogledal, BI VIDEL razliko. (condizionale semplice: Se guardasse meglio vedrebbe la differenza.) /If he took a better look, he would see the difference./

19. Če bi bolje pogledal, BI VIDEL razliko. (condizionale composto: Se avesse guardato meglio avrebbe visto la differenza.) If he had taken a better look he would have seen the difference./

20. Poskušal bo oditi ven, ne da BI ga kdo VIDEL. (presente del congiuntivo: Cercherà di uscire senza che qualcuno lo veda.) /He will try to go out without being noticed by anyone./

21. Odšel je ven, ne da BI ga kdo VIDEL.

(imperfetto del congiuntivo: È uscito senza che qualcuno lo vedesse.) /He went out without being noticed by anyone./ 
22. Dokument potem odnesejo, ne da BI ga ravnatelj VIDEL.

(passato del congiuntivo: Poi portano via il documento senza che il preside l'abbia visto.)

/Then they take away the document without the headmaster having seen it./

23. Dokument so odnesli, ne da BI jih ravnatelj VIDEL.

(trapassato del congiuntivo: Portarono via il documento senza che il preside l'avesse visto.)

/They took away the document without the headmaster having seen it./

\section{THE ITALIAN TENSE FORMS IN THE CLASSROOM}

In view of such a general lack of correspondence between the functioning of tenses in the two languages - not to mention the number of forms a language learner has to master due to the multiplicity and complexity of conjugation patterns - it is obvious that the bulk of knowledge to be acquired in the area of Italian verb grammar alone is extremely large. Understandably, linguists who have studied the functioning of tenses would like to see their findings to be taken into account in the classroom, so that language learners would ultimately be able to use correctly the tense forms indispensable for the expression of important logico-semantic relations. In reality, however, grammatical issues are currently not considered a priority in language teaching; 9 practitioners are often convinced that the emphasis should be placed on other, allegedly »more important « aspects, such as the lexicon, cultural issues, different communication skills, etc.

In view of the fact that both, the linguist and the practically-minded language teacher are to a certain extent right, in all teaching situations reasonable compromises should be reached. For instance, in teacher-training courses at university level a thorough transmission of experts' findings can and should be carried out. And indeed, in our own teaching the functioning of the Slovene and Italian verb systems is systematically dealt with from a contrastive perspective and in dependence of a number of parameters in real texts, from short informative to literary ones (see Miklič 2005; cfr. also McCarthy/Carter 1994: 98-100), and it is often further exemplified by translation exercises and by the study of translated texts (cfr. Ožbot 2004); the textual approach employed is supported by graphic representations of temporal relations (cfr. Miklič $1997,2003,2004$ ). For the sake of illustration, an example is given by the following text and its visual translation:

9 Cfr. Common European Framework of Reference for Language Learning and Teaching and Italian language syllabus for Slovene secondary schools (http://www.mszs.si/slo/solstvo/razvoj_solstva/viprogrami/pdf/' Ita 01.pdf). 
24. Una delle più confortevoli fermate di autobus che si conoscono $(\operatorname{Pr})$ è $(\operatorname{Pr})$ nell'isola di Unst, la più settentrionale delle Shetland, in Scozia. Essa era stata soppressa (TP), però l'intraprendente Bobby Macaulay, che non voleva (IM) darsi per vinto, scrisse (PR) al gionale locale promettendo (G) che se fosse stata ripristinata (TP') se ne sarebbe preso (CC) cura lui stesso. Così, dopo averla riottenuta, (INF2) l'ha abbellita (PP) con tende ricamate e fiori, l'ha arredata (PP) con un divano e un tavolino, e cerca (Pr) di non farvi mai mancare spuntini caldi: [...]. (La Settimana Enigmistica, No 3781, p. 12)

Pr - presente

PP - passato prossimo

PR - passato remoto

IM - imperfetto

TP - trapassato prossimo

TP'- trapassato del congiuntivo

$\mathrm{CC}$ - condizionale composto

INFF - infinito composto

$\mathrm{G}$ - gerundio

/One of the most comfortable bus-stops ever known can be found on the island of Unst, the northernmost of the Shetland Islands, Scotland. It was eliminated, but the enterprising Bobby Macauley, who would not give up, wrote to the local newspaper promising to take care of it himself if it was restored. So, after the bus stop was re-established, he embellished it with flower-embroidered courtains, furnished it with a sofa and a coffee table, and now he makes every attempt to keep it supplied with warm snacks: [...]./

But this approach, directed towards enabling students to use the foreign language productively, is, clearly, not applicable to other Italian-language teaching situations. For instance, history students will have to know the verb form usage relatively well, but above all in a receptive way, to be able to make use of linguistically complex bibliographical resources. On the other hand, learners in vocational schools, let us say those training to become waiters, need a more restricted knowledge, which, however, must be of a more productive kind.

Now, returning to the secondary school as the fundamental type of educational institution as far as foreign language learning is concerned, it should be pointed out that the strictly progressive (from formally simple to complex), limitative (only some tenses are introduced) and non contrastive (cfr. Marin/Magnelli 2003a, 2003b, 2003c; Mezzadri/ 
Balboni 2000, 2001, 2003) approaches currently prevailing in it cannot normally bring good results. The pupils are not explicitly taught models for the expression of logicosemantic relations to which they have access in their mother tongue; all too many syntactic constructions remain in fact unknown to them simply because they have not learned the appropriate tenses. In such a situation, teachers often stick to the prescribed syllabus as much as they can. Although many confess that the inherited approach is not satisfying, they are reluctant to any change because they already feel overburdened.

In the conviction that the learner should be treated in a more intelligent way (cfr. Miklič/Ožbot 2001) and that an understanding of the functioning of the two verb systems can only be achieved if it is approached as a problem-solving task, our proposal for teaching the uses of Italian verb forms to the speakers of Slovene - and also to speakers of other languages which display similar structural and functional discrepancies with respect to the Italian verb system - is as follows: given that the majority of secondary-school learners will not be offered other formal language education later in life, they should acquire at this very stage a well-balanced amount of grammatical and communicative knowledge, and, above all, they should be helped in the development of their general language awareness. ${ }^{10}$ To achieve this, it is sensible to introduce as soon as possible the whole Italian verb system, which can subsequently help the learner in solving receptive tasks (reading and listening), and it is important for him/her to get acquainted with its complexity in a »)user-friendly « manner. Therefore, from the outset, the verb forms should be presented not learned - and the so-called morphologically complex tenses should be introduced in different types of attractive, witty or mind-provoking short texts like proverbs, aphorisms, sayings, but also poems, songs and slogans used as chunks of language to be understood and, consequently, memorized. The verb form and the syntactic construction would be offered as a medicine in a chocolate-covered pill. Here are some examples on the basis of which the learner can gain familiarity with the uses of single Italian tenses:"

TP Qualunque cosa vada male, c'è sempre qualcuno che l'aveva detto. (A. Bloch) Whatever goes wrong, there is always someone who foresaw it./

IM' - Chi promette tutto è come se non prometesse nulla. (B. Gracián) /To promise everything is to promise nothing./

TP' Se non si parla di una cosa è come se non fosse mai accaduta. Si dà realtà alle cose solo quando se ne parla. (O. Wilde)

/If something is not spoken about it is as if it had never happened. Things become real only when they are spoken about./

IM'/C - In amore l'esperienza non conta nulla, perché se contasse nessuno amerebbe più. (H. De Régnier)

In love, experience does not count at all; if it did, no one would love any more./

${ }^{10}$ On the role of language awareness in second-language learning cfr. Cook (2001: 42); for a case study on the enhancement of grammatical consciousness see Yip 1994.

11 All these examples are taken from Il libro degli aforismi edited by Federico Roncoroni (Milano, Oscar Mondadori, 1989). 
TP'/CC Se Dio avesse avuto intenzione di far vivere e agire gli uomini nella verità, avrebbe dovuto disporre altrimenti le cose. (J.W. Goethe)

If God had had the intention to make people live and act in truth, he would have had to dispose things in a different way./

IM/IM' I nomi collettivi servono a far confusione. »Popolo, pubblico... « Un bel giorno ti accorgi che siamo noi. Invece credevi che fossero gli altri. (E. Flaiano) /Collective nouns serve to create confusion. "People, public, etc.« One day you suddenly realize that they refer to us. Whereas you thought they referred to others./

By getting acquainted with such texts and by succeeding in their reproduction the learner could very soon experience the rewarding feeling of being able to express an intelligent, semantically rich and linguistically complex content, and the beneficial effects of the victory over difficulties may prepare the ground for guided, autonomous or spontaneous learning at a later moment. It goes without saying that the productive use of selected tenses continues to be introduced, according to the goals of a given syllabus, at different stages. In addition to this, one can only determine which particular segments to include in different curricula in collaboration with language teachers, who are normally better acquainted with the learner's interests and could thus contribute substantially to the preparation of efficient and attractive teaching materials.

\section{Select Bibliography}

BANFI, E./A. GIACALONE RAMAT (2003) "Verbi italiano e cinese a confronto e questioni di acquisizione del verbo italiano da parte di sinofoni. « In: M. Giacomo-Marcellesi /A. Rocchetti (eds), 461-488.

BARNI, M./F. CARLONI/S. LUCARELLI (2003) »Il verbo nei materiali didattici per immigrati stranieri.« In: M. Giacomo-Marcellesi /A. Rocchetti (eds), 535-551.

BRAIDI, S. (1999) The Acquisition of Second Language Syntax. London: Arnold.

Common European Framework of Reference for Language Learning and Teaching: Language Learning for European Citizenship. Strasbourg: Council of Europe, 1996.

COOK, V. ( $\left.{ }^{2} 2001\right)$ Second Language Learning and Teaching. London: Arnold.

GIACALONE RAMAT, A. (ed.) (1988) L'italiano tra le altre lingue: strategie di acquisizione. Bologna: Il Mulino.

GIACOMO-MARCELLESI, M./A. ROCCHETTI (eds) (2003)Ilverbo italiano: Studi diacronici, sincronici, contrastivi, didattici. Roma: Bulzoni.

MARIN, T./S. MAGNELLI (2003a) Progetto italiano 1: corso di lingua e civiltà italiana. Livello elementare. Atene: EdiLingua.

MARIN, T./S. MAGNELLI (2003b) Progetto italiano 2: corso di lingua e civiltà italiana. Livello elementare. Atene: EdiLingua.

MARIN, T./S. MAGNELLI (2003c) Progetto italiano 2: corso di lingua e civiltà italiana. Livello elementare. Atene: EdiLingua.

McCARTHY, M./R. CARTER (1994) Language as Discourse: Perspectives for Language Teaching. London: Longman.

MEZZADRI, M./P. E. BALBONI (2000) Rete! Corso multimediale d'italiano per stranieri, 1. Perugia: Guerra.

MEZZADRI, M./P. E. BALBONI (2001) Rete! Corso multimediale d'italiano per stranieri, 2. Perugia: Guerra.

MEZZADRI, M./P. E. BALBONI (2003) Rete! Corso multimediale d'italiano per stranieri, 3. Perugia: 
Guerra.

MERTELJ, D. (2005) Poučevanje nekaterih podrednih skladenjskih vzorcev pri predmetu »italijanščina" kot tuji jezik $v$ slovenskih gimnazijah: sedanje stanje in predlogi za spremembe. doktorska disertacija. Ljubljana: Filozofska fakulteta, Oddelek za romanske jezike in književnosti.

MIKLIČ, T. (1983) »L'opposizione italiana PERFETTO vs IMPERFETTO e l'opposizione slovena DOVRŠNOST vs NEDOVRS̆NOST nella verbalizzazione delle azioni passate.« Linguistica 23, 53-123.

MIKLIČ, T. (1991) »Forme verbali italiane: come vengono presentate dalle grammatiche e come funzionano nei testi.« Scuola Nostra 23, 87-103.

MIKLIČ, T. (1992a) »La Consecutio Temporum in sloveno e in italiano: alcune osservazioni.« In: A. G. Mocciaro/G. Soravia (eds), L'Europa linguistica: contatti, contrasti, affinità di lingue. Roma: Bulzoni, $189-218$.

MIKLIČ, T. (1992b) »Tendenze nella scelta delle forme verbali italiane in testi prodotti da apprendenti sloveni: in cerca di spie dell'interferenza.« In: B. Moretti et al. (eds), Linee di tendenza dell'italiano contemporaneo. Roma: Bulzoni, 475-492.

MIKLIČ, T. (1993) "Skladnja« and »Kontrastiranje rab slovenskih glagolskih oblik z italijanskimi«. In: Italijanski jezik: predmetni izpitni katalog za maturo. Ljubljana: Republiški izpitni center, 103-122; 246-259.

MIKLIČ, T. (1997) »Segnalazione della temporalità nel testo: che cosa aiuta il ricevente a collocare le azioni sull'asse temporale. «In: L.Agostiniani et al. (eds), Atti del Terzo Convegno della Società Internazionale di Linguistica e Filologia Italiana. Napoli: Edizioni Scientifiche Italiane, 477-505.

MIKLIČ, T. (2003) »Interpretazione della funzione testuale dei paradigmi verbali italiani. Tentativo di un modello d'analisi integrata.« In: M. Giacomo-Marcellesi /A. Rocchetti (eds), 553-570.

MIKLIČ, T. (2004) »Testi narrativi, azioni centrali e paradigmi verbali italiani.« In: Paolo D'Achille (ed.), Generi, architetture e forme testuali. Firenze: F. Cesati, 145-160.

MIKLIČ, T. (2005) »Testo letterario in classe d'italiano L2: Come aiutare lo studente ad esplorare il lato espressivo dell'opera per capirla e gustarla meglio.« In: C. Lavinio (ed.), Educazione linguistica e educazione letteraria: intersezioni e interazioni. Milano: FrancoAngeli, 286-293.

MIKLIČ, T./M. OŽBOT (2001) "L'insegnamento dell'italiano in Slovenia.« Bulletin VALS-ASLA 73, $113-121$.

MODERC, S. (2003) "L'acquisizione dell'imperfetto da parte di discenti aventi come lingua madre il serbocroato. Problemi aspettuali e temporali火. In: M. Giacomo-Marcellesi /A. Rocchetti (eds), 571-584.

OŽBOT, M. (1995/96) »Romanske jezikovne prvine v besedilu Rapsodija v treh stavkih Mirana Košute.« Jezik in slovstvo 41 (junij 1995/96), 379-385.

OŽBOT, M. (2004) »Tradurre per sbagliare, tradurre per imparare.« Linguistica 44, 47-58.

URŠIČ, M. et al. (eds) (2000) Italijanski jezik: Predmetni izpitni katalog za maturo. Ljubljana: Državni izpitni center, 91-115.

YIP, V. (1994) »Grammatical consciousness-raising and leamability.« In: T. Odlin (ed.), Perspectives on Pedagogical Grammar. Cambridge: Cambridge University Press, 123-238.

\section{Povzetek}

\section{POUČEVANJE RAB ITALIJANSKIH GLAGOLSKIH PARADIGEM PRI GOVORCIH SLOVENŠČINE}

$\mathrm{V}$ članku so najprej predstavljena nekatera opažanja o poučevanju italijanskih glagolskih paradigem pri slovenskih govorcih, zbrana na osnovi pedagoških in raziskovalnih izkušenj, nato pa je ponujenih nekaj sugestij za produktivno usvajanje glagolskih oblik pri pouku tujega jezika. Avtorici vztrajata na eksplicitnem poučevanju slovnice tujega jezika - tudi v primerjavi z materinščino -, in sicer prvič zato, ker je za govorce številčno majhnega jezika, kot je slovenščina, bistveno produktivno in kvalitetno znanje tujih jezikov, saj so $\mathrm{v}$ mednarodni komunikacji $\mathrm{v}$ veliki večini najrazličnejših situacij prav govorci majhnih jezikov tisti, ki se morajo biti sposobni sporazumevati v tujih jezikih, glede na to, da je tujih govorcev, ki znajo jezike, kot je slovenščina, sorazmerno zelo malo; drugič, potrebo po eksplicitnem poučevanju slovnice narekujejo tudi sistemske značilnosti italijanskega jezika, $z$ visokim številom glagolskih paradigem, ki se uporabljajo pri izražanju različnih časovnih, aspektualnih in modalnih pomenov ter pomembnih logično-semantičnih 
vsebin. Po teh značilnostih se italijanščina v veliki meri razlikuje od slovenščine, brez njihovega izrecnega poudarjanja pa bi te tazlike ostale premalo zaznane ali celo povsem neopažene.

Ob zgledih iz slovenščine, italijanščine in deloma angleščine so predstavljeni nekateri najtipičnejši problemi slovenskih govorcev pri usvajanju tujih jezikov, ki izhajajo iz različnih principov izbire glagolskih paradigem v posameznih jezikih. Podanih je nekaj predlogov za poučevanje glagolskih oblik pri slovenskih govorcih (in pri govorcih drugih jezikov, ki izkazujejo podobne strukturne razlike v odnosu do italijanskega glagolskega sistema), pri čemer je poudarjeno, da je glagolske oblike treba uvajati $v$ njihovi kompleksnosti in da je smiselno posvečati pozornost tako leksikalnim kot gramatikalnim vidikom ter pri poučevanju vključiti konkretne kratke jezikovno kompleksne in vsebinsko zanimive ali miselno izzivalne tekste (pregovore, aforizme, izreke pa tudi pesmi, songe in slogane), ki si jih učenci lahko zapomnijo, reproducirajo in v katerih je mogoče na privlačen način spoznavati besedilno funkcioniranje posameznih italijanskih glagolskih paradigem. 